\title{
Synthesis, Antimicrobial and Antioxidant Activities of Novel series of Cin- namamide Derivatives having Morpholine Moiety
}

\section{Gangadhara Seelolla, Prasad Cheera and Venkateswarlu Ponneri*}

Department of Chemistry, Sri Venkateswara University, Tirupati 517 502, AP, India

\begin{abstract}
Structurally morpholine containing Cinnamamide derivatives have been synthesized in quantitative yields by the reaction of different substituted cinnamicacids with morpholine. The structures of the newly synthesized compounds were confirmed by their IR, LC-MS, ${ }^{1} \mathrm{H} \&{ }^{13} \mathrm{C}-\mathrm{NMR}$ spectral data. The synthesized compounds were evaluated for their antimicrobial activity against bacterial species Bacillus subtilis and Escherichia coli etc and in vitro antioxidant activity by employing DPPH, hydrogen peroxide, and nitric oxide radical scavenging assays. Among these prepared compounds $4 \mathrm{i}$ and $4 \mathrm{j}$ showed significant antioxidant, antibacterial as well as antifungal activity and these were found to be the most potent activity molecules when compared with that of standard drugs.
\end{abstract}

Keywords: Morpholine; Cinnamic acid; Amide; Antioxidant property; Antimicrobial activity

\section{Introduction}

Cinnamic acid, which is ubiquitous in cinnamon oil and many other balsams, is a naturally occurring aromatic fatty acid of low toxicity with a long history of human exposure [1]. Commercially, it is widely applied in the perfume industry because of its floral odor. In recent years, cinnamic acid derivatives have attracted much attention due to their antioxidative [2], antitumor [3] and antimicrobial properties [4]. Though some of the research papers on cinnamic acid derivatives were reported as antitubercular agents [5-8]. Among these cinnamic acid derivatives such as cinnamamides were reported to have many different biological activities such as anticancer, antimitotic, antioxidant and seed-germination inhibitory effects [9-11] and some of the cinnamamide derivatives exhibit a variety of biological activities, for example as shown in Figure 1, the genus piperaceae molecules (A) have been widely studied, due to the biological properties of secondary metabolites from these plants [12-14]. The natural piperidine derivative (B) showed good insecticidal activity against the fall armyworm, Spodoptera frugiperda [15]. Compounds (C) represent a novel series of potent small molecule inhibitors that not only have excellent in vitro profiles but also have activity in vivo [16]. N-(2-hydroxy ethyl) cinnamamide (D) was found to posses good anticonvulsant activity and also low toxicity [17]. . In addition, in the course of screening compounds for pharmacological action, it was observed that $\alpha$-phenyl$\mathrm{N}, \mathrm{N}$-diethyl cinnamamide potentiated Nembutal hypnosis in rats [18].

On the other hand, among the family of heterocyclic compounds,<smiles>[R20]c1c(OC)cc(/C=C/C(=O)N2CCC=CC2=O)cc1OC</smiles><smiles>O=C(/C=C/c1ccc2c(c1)OCO2)N1CCCCC1</smiles><smiles>[R3]N([R])C(=O)/C=C/c1ccc(-c2[nH]c([Hg])nc2-c2ccc(/C=C/C(=O)O)cc2)cc1</smiles>

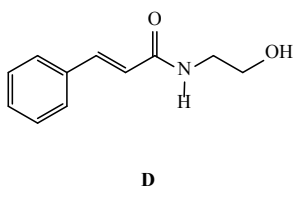

Figure 1. Examples of molecule containing cinnamamide derivatives. the heterocycles with $\mathrm{N}, \mathrm{S}$ and $\mathrm{O}$ atoms have attracted the attention of chemical research due to their wide spectrum of biological activities. $\mathrm{N}$ and $\mathrm{O}$ atoms containing Morpholine has its unique position in heterocyclic chemistry, and its derivatives are gaining considerable importance due to diverse biological activities such as antimalarial [19], antibacterial [20], antimicrobial [21,22], antidepressant [23], antiproliferative [24], hypocholesterolemic [25], antibiotic, antileukemic [26,27]etc.

Many efforts to find and develop novel and more potent antioxidants without side effects, and effective antimicrobial derivatives become increasingly important in the food and the cosmetic industries, and in medicine. Because of the constrained availability of natural cinnamic acid analogues, the establishment of their biological activities is still limited. Therefore, we synthesized a series of morpholine containing cinnamamide derivatives and evaluated their antimicrobial effects and antioxidant properties.

\section{Experimental Section}

\section{Chemistry}

Melting points were determined in open capillaries on a MelTemp apparatus and are uncorrected. All the reactions were monitored by thin layer chromatography (TLC) on precoated silica gel 60 F254 (mesh); spots were visualized with UV light. Merck silica gel (60-120 mesh) was used for column chromatography. The IR spectra were recorded on a Perkin-Elmer BX1 FTIR Spectrophotometer using $\mathrm{KBr}$ pellets and the wave numbers were given in $\mathrm{cm}^{-1} .{ }^{1} \mathrm{H} \mathrm{NMR}(400 \mathrm{MHz})$, and ${ }^{13} \mathrm{C}$ NMR $(100 \mathrm{MHz})$ spectra were recorded on a Bruker AMX $400 \mathrm{MHz}$ NMR spectrometer in $\mathrm{CDCl}_{3} / \mathrm{DMSO}-d_{6}$ solution using TMS as an internal standard. All chemical shifts were reported in $\delta$ (ppm) using TMS as an internal standard. The mass spectra were recorded on Agilent $1100 \mathrm{LC} / \mathrm{MSD}$ instrument with method API-ES at $70 \mathrm{eV}$.

${ }^{*}$ Corresponding author: Venkateswarlu Ponneri, Department of Chemistry, Sri Venkateswara University, Tirupati 517 502, AP, India, Tel: 91-9393600444, E-mail: chem.ponneri@gmail.com

Received October 19, 2014; Accepted December 09, 2014; Published December 10,2014

Citation: Seelolla G, Cheera P, Ponneri V (2014) Synthesis, Antimicrobial and Antioxidant Activities of Novel series of Cinnamamide Derivatives having Morpholine Moiety. Med chem 4: 778-783. doi:10.4172/2161-0444.1000229

Copyright: ( 2014 Seelolla G, et al. This is an open-access article distributed under the terms of the Creative Commons Attribution License, which permits unrestricted use, distribution, and reproduction in any medium, provided the original author and source are credited. 
The microanalyses were performed on a Perkin Elmer 240C elemental analyzer. The antioxidant property was carried out by using Shimadzu UV-2450s spectrophotometer.

\section{General Procedure for the Synthesis of trans cinnamamides $(4 a-j)$}

In this reaction, a mixture of phenyl substituted cinnamic acid (4aj) and $\mathrm{SOCl}_{2}$ (which acted as both reactant and solvent) was stirred and refluxed at $80-90^{\circ} \mathrm{C}$ for $4 \mathrm{hrs}$. Remaining $\mathrm{SOCl}_{2}$ was removed by distillation under reduced pressure. Thus, the intermediate acid chloride (2a-j) was added drop wise to $0^{\circ} \mathrm{C}$ cooled solution of morpholine (3) in dry pyridine to give product cinnamamide $(4 \mathrm{a}-\mathrm{j})$ with good yield as described in scheme 1 .

\section{(E)-1-morpholino-3-phenylprop-2-en-1-one (4a)}

Color less solid; Yield $72 \%$; $\mathrm{mp}: 158-160^{\circ} \mathrm{C}$; IR $\left(\mathrm{KBr}, \mathrm{cm}^{-1}\right)$ : $1660(\mathrm{C}=\mathrm{O}), 1580$ (C=C), 1170 (C-O); ${ }^{1} \mathrm{H}-\mathrm{NMR}$ (DMSO-d6) $\delta: 7.48$ (d, $2 \mathrm{H},-\operatorname{ArH}), 7.22(\mathrm{t}, 1 \mathrm{H},-\mathrm{ArH}), 6.83$ (dd, 2H, -ArH), $6.72(\mathrm{~d}, 1 \mathrm{H}$, $=\mathrm{CH}), 7.11(\mathrm{~d}, 1 \mathrm{H},=\mathrm{CH}), 2.50\left(\mathrm{t}, 2 \mathrm{H},-\mathrm{CH}_{2}\right), 2.14\left(\mathrm{t}, 2 \mathrm{H},-\mathrm{CH}_{2}\right) ;{ }^{13} \mathrm{C}$ NMR (DMSO-d6) $\delta$ (ppm) : 158.4, 140.2, 135.3, 127.7, 127.3, 126.4, 115.8, 59.6, 44.8; MS: $\mathrm{m} / \mathrm{z} 218(\mathrm{M}+\mathrm{H})^{+}$for $\mathrm{C}_{13} \mathrm{H}_{15} \mathrm{NO}_{2}$; Anal. calcd.for $\mathrm{C}_{13} \mathrm{H}_{15} \mathrm{NO}_{2}$ : C 71.87, H 6.96, N 6.45; Found: C 71.80, H 6.94, N 6.40\%.

\section{(E)-3-(2-chlorophenyl)-1-morpholinoprop-2-en-1-one (4b)}

Pale yellowish brown solid in $70 \%$; mp: $188-190^{\circ} \mathrm{C}$; $\mathrm{IR}\left(\mathrm{KBr}, \mathrm{cm}^{-1}\right)$ : $1675(\mathrm{C}=\mathrm{O}), 1550(\mathrm{C}=\mathrm{C}), 1140(\mathrm{C}-\mathrm{O}) ;{ }^{1} \mathrm{H}-\mathrm{NMR}$ (DMSO-d6) $\delta: 7.80(\mathrm{~d}$, $1 \mathrm{H},-\mathrm{ArH}), 7.57(\mathrm{~d}, 1 \mathrm{H},-\mathrm{ArH}), 7.26(\mathrm{t}, 2 \mathrm{H},-\mathrm{ArH}), 7.39(\mathrm{~d}, 1 \mathrm{H},=\mathrm{CH})$, $7.99(\mathrm{~d}, 1 \mathrm{H},=\mathrm{CH}), 3.50\left(\mathrm{t}, 2 \mathrm{H},-\mathrm{CH}_{2}\right), 3.72\left(\mathrm{t}, 2 \mathrm{H},-\mathrm{CH}_{2}\right) ;{ }^{13} \mathrm{C} \mathrm{NMR}$
$(\mathrm{DMSO}-d 6) \delta(\mathrm{ppm}): 165.2,138.9,134.6,133.6,130.3,130.1,127.6$, 126.9, 119.9, 66.8, 47.4; MS: $\mathrm{m} / \mathrm{z} 252(\mathrm{M}+\mathrm{H})^{+}$for $\mathrm{C}_{13} \mathrm{H}_{14} \mathrm{ClNO}_{2}$; Anal. calcd.for $\mathrm{C}_{13} \mathrm{H}_{14} \mathrm{ClNO}_{2}$ : C 62.03, H 5.61, N 5.56; Found: C 61.94, H 5.59, N 5.51\%.

\section{(E)-3-(2-methoxyphenyl)-1-morpholinoprop-2-en-1-one (4c)}

Color less solid; Yield $68 \%$; mp: $168-170^{\circ} \mathrm{C}$; IR $\left(\mathrm{KBr}, \mathrm{cm}^{-1}\right): 1680$ $(\mathrm{C}=\mathrm{O}), 1545(\mathrm{C}=\mathrm{C}), 1130(\mathrm{C}-\mathrm{O}) ;{ }^{1} \mathrm{H}-\mathrm{NMR}$ (DMSO-d6) $\delta: 7.33$ (dd, $1 \mathrm{H}$, -ArH), 6.97 (d, 1H, -ArH), $6.93(\mathrm{dd}, 1 \mathrm{H},-\mathrm{ArH}), 6.89$ (d, 1H, -ArH), $7.91(\mathrm{~d}, 1 \mathrm{H},=\mathrm{CH}), 7.46(\mathrm{~d}, 1 \mathrm{H},=\mathrm{CH}), 3.87\left(\mathrm{~s}, 3 \mathrm{H},-\mathrm{OCH}_{3}\right), 3.70(\mathrm{~m}, 8 \mathrm{H}$, $-\mathrm{CH}$ ); ${ }^{13} \mathrm{C}$ NMR (DMSO-d6) $\delta$ (ppm) : 166.2, 158.2, 138.6, 130.7, 129.0, 124.2, 120.6, 111.6, 111.2, 66.8, 55.4, 53.3; MS: $\mathrm{m} / \mathrm{z} 248(\mathrm{M}+\mathrm{H})^{+}$for $\mathrm{C}_{14} \mathrm{H}_{17} \mathrm{NO}_{3}$; Anal. calcd. for $\mathrm{C}_{14} \mathrm{H}_{17} \mathrm{NO}_{3}: \mathrm{C} 68.00, \mathrm{H}$ 6.93, N 5.66; Found: C 67.91, H 6.90, N 5.60\%.

\section{(E)-3-(3-methoxyphenyl)-1-morpholinoprop-2-en-1-one (4d)}

Pale yellow solid in $70 \%$; $\mathrm{mp}: 169-171^{\circ} \mathrm{C}$; $\mathrm{IR}\left(\mathrm{KBr}, \mathrm{cm}^{-1}\right): 1665$ $(\mathrm{C}=\mathrm{O}), 1530(\mathrm{C}=\mathrm{C}), 1070(\mathrm{C}-\mathrm{O}) ;{ }^{1} \mathrm{H}-\mathrm{NMR}$ (DMSO-d6) $\delta: 7.34(\mathrm{~d}, 1 \mathrm{H}$, -ArH), 7.32 (d, 1H, -ArH), 6.95 (dd, 1H, -ArH), 7.28 (d, 1H,-ArH), $7.49(\mathrm{~d}, 1 \mathrm{H},=\mathrm{CH}), 7.24(\mathrm{~d}, 1 \mathrm{H},=\mathrm{CH}), 3.81\left(\mathrm{~s}, 3 \mathrm{H},-\mathrm{OCH}_{3}\right), 3.62(\mathrm{~m}$, $8 \mathrm{H},-\mathrm{CH}) ;{ }^{13} \mathrm{C}$ NMR (DMSO-d6) $\delta$ (ppm) : 160.9, 158.4, 140.1, 136.7, $130.3,127.7,122.1,115.8,111.7,107.6,62.2,55.5,46.2 ; \mathrm{MS}: \mathrm{m} / \mathrm{z} 248$ $(\mathrm{M}+\mathrm{H})^{+}$for $\mathrm{C}_{14} \mathrm{H}_{17} \mathrm{NO}_{3}$; Anal. calcd.for $\mathrm{C}_{14} \mathrm{H}_{17} \mathrm{NO}_{3}$ : C 68.00, H 6.93, N 5.66; Found: C 67.91, H 6.90, N 5.60\%.

\section{(E)-3-(4-methoxyphenyl)-1-morpholinoprop-2-en-1-one (4e)}

Color less solid in $71 \%$; mp: $166-169^{\circ} \mathrm{C}$; $\mathrm{IR}\left(\mathrm{KBr}, \mathrm{cm}^{-1}\right): 1640(\mathrm{C}=\mathrm{O})$,

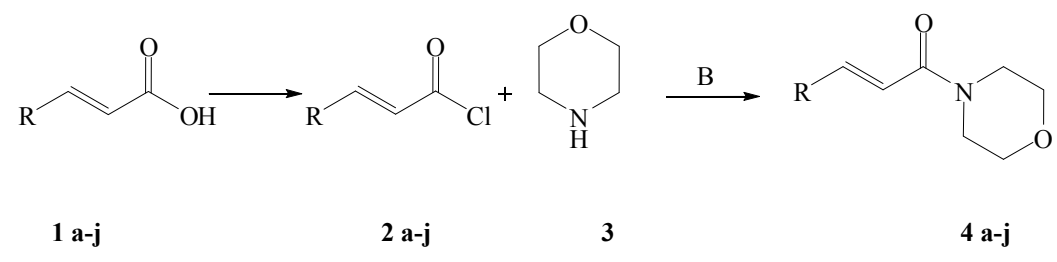

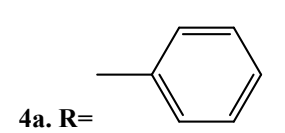

4a. $R=$

4b. $R=$

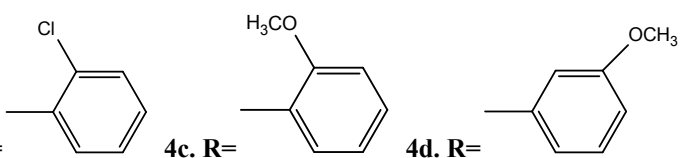

4e. $R=$<smiles>COc1ccc(C)cc1</smiles>

4f. $R=$<smiles>COc1ccc(C)c(OC)c1</smiles>

4g. $R=$<smiles>COc1ccc(C)cc1OC</smiles>

4h. $\mathbf{R}=$

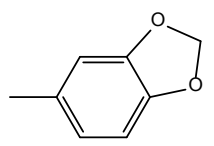

4i. $\mathbf{R}=$

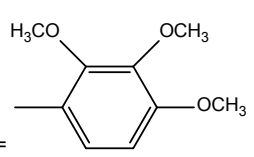

4j. $R=$

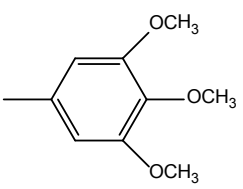

Scheme 1: 
$1540(\mathrm{C}=\mathrm{C}), 1090$ (C-O); ${ }^{1} \mathrm{H}-\mathrm{NMR}$ (DMSO-d6) $\delta: 7.58$ (d, 2H, -ArH), $6.95(\mathrm{~d}, 2 \mathrm{H},-\mathrm{ArH}), 7.29(\mathrm{~d}, 1 \mathrm{H},=\mathrm{CH}), 7.04(\mathrm{~d}, 1 \mathrm{H},=\mathrm{CH}), 3.62(\mathrm{~s}, 3 \mathrm{H}$, $\left.-\mathrm{OCH}_{3}\right), 3.43(\mathrm{~m}, 8 \mathrm{H},-\mathrm{CH}) ;{ }^{13} \mathrm{C}$ NMR (DMSO-d6) $\delta$ (ppm) : 162.9, 159.2, 140.1, 132.7, 128.3, 115.8, 111.7, 66.2, 55.8, 43.0; MS: m/z 248 $(\mathrm{M}+\mathrm{H})^{+}$for $\mathrm{C}_{14} \mathrm{H}_{17} \mathrm{NO}_{3}$; Anal. calcd. for $\mathrm{C}_{14} \mathrm{H}_{17} \mathrm{NO}_{3}: \mathrm{C} 68.00, \mathrm{H} 6.93, \mathrm{~N}$ 5.66; Found: C 67.91, H 6.90, N 5.60\%.

\section{(E)-3-(2,4-dimethoxyphenyl)-1-morpholinoprop-2-en-1-one (4f)}

Color less solid in $70 \%$; mp: $174-176^{\circ} \mathrm{C}$; $\mathrm{IR}\left(\mathrm{KBr}, \mathrm{cm}^{-1}\right): 1666(\mathrm{C}=\mathrm{O})$, $1536(\mathrm{C}=\mathrm{C}), 1140(\mathrm{C}-\mathrm{O}) ;{ }^{1} \mathrm{H}-\mathrm{NMR}(\mathrm{DMSO}-\mathrm{d6}) \delta: 7.78(\mathrm{~d}, 1 \mathrm{H},-\mathrm{ArH})$, $6.60(\mathrm{~d}, 1 \mathrm{H},-\mathrm{ArH}), 6.55(\mathrm{~s}, 1 \mathrm{H},-\mathrm{ArH}), 7.69(\mathrm{~d}, 1 \mathrm{H},=\mathrm{CH}), 7.02(\mathrm{~d}, 1 \mathrm{H}$, $=\mathrm{CH}), 3.85\left(\mathrm{~s}, 3 \mathrm{H},-\mathrm{OCH}_{3}\right), 3.59\left(\mathrm{~s}, 3 \mathrm{H},-\mathrm{OCH}_{3}\right), 3.38(\mathrm{~m}, 8 \mathrm{H},-\mathrm{CH})$; ${ }^{13} \mathrm{C}$ NMR (DMSO-d6) $\delta(\mathrm{ppm}): 165.22,161.98,158.93,136.3,129.1$, 116.4, 114.8, 105.8, 98.2, 66.2, 55.6, 55.5, 44.3; MS: $\mathrm{m} / \mathrm{z} 278(\mathrm{M}+\mathrm{H})^{+}$for $\mathrm{C}_{15} \mathrm{H}_{19} \mathrm{NO}_{4}$; Anal. calcd.for $\mathrm{C}_{15} \mathrm{H}_{19} \mathrm{NO}_{4}$ : C 64.97, $\mathrm{H}$ 6.91, N 5.05; Found: C 64.90, H 6.88, N 5.01\%.

\section{(E)-3-(3,4-dimethoxyphenyl)-1-morpholinoprop-2-en-1-one (4g)}

Color less solid in $68 \%$; $\mathrm{mp}: 176-179^{\circ} \mathrm{C}$; $\mathrm{IR}\left(\mathrm{KBr}, \mathrm{cm}^{-1}\right): 1683$ $(\mathrm{C}=\mathrm{O}), 1526(\mathrm{C}=\mathrm{C}), 1133(\mathrm{C}-\mathrm{O}){ }^{1}{ }^{1} \mathrm{H}-\mathrm{NMR}$ (DMSO-d6) $\delta: 7.35(\mathrm{~s}, 1 \mathrm{H}$, -ArH), 7.19 (dd, 1H, -ArH), 7.08 (d, 1H, -ArH), $7.44(\mathrm{~d}, 1 \mathrm{H},=\mathrm{CH}), 6.95$ $(\mathrm{d}, 1 \mathrm{H},=\mathrm{CH}), 3.82\left(\mathrm{~s}, 3 \mathrm{H},-\mathrm{OCH}_{3}\right), 3.71\left(\mathrm{~s}, 3 \mathrm{H},-\mathrm{OCH}_{3}\right), 3.60(\mathrm{~m}, 8 \mathrm{H}$, $-\mathrm{CH}) ;{ }^{13} \mathrm{C}$ NMR (DMSO-d6) $\delta$ (ppm) : 160.2, 150.5, 149.5, 138.7, 128.3, 122.1, 115.8, 111.7, 107.6, 68.6, 55.6, 48.4; MS: m/z $278(\mathrm{M}+\mathrm{H})^{+}$for $\mathrm{C}_{15} \mathrm{H}_{19} \mathrm{NO}_{4}$; Anal. calcd.for $\mathrm{C}_{15} \mathrm{H}_{19} \mathrm{NO}_{4}$ : C 64.97, $\mathrm{H}$ 6.91, N 5.05; Found: C 64.90, H 6.88, N 5.01\%.

E)-3-(benzo[d] [1,3] dioxol-5-yl)-1-morpholinoprop-2-en-1one $(4 h)$

Pale yellow solid in $71 \%$; $\mathrm{mp}$ : $179-181^{\circ} \mathrm{C}$; $\mathrm{IR}\left(\mathrm{KBr}, \mathrm{cm}^{-1}\right): 1675$ $(\mathrm{C}=\mathrm{O}), 1580(\mathrm{C}=\mathrm{C}), 1149(\mathrm{C}-\mathrm{O}){ }^{1} \mathrm{H}-\mathrm{NMR}$ (DMSO-d6) $\delta: 7.41(\mathrm{~s}, 1 \mathrm{H}$, -ArH), $7.15(\mathrm{dd}, 1 \mathrm{H},-\mathrm{ArH}), 6.92(\mathrm{~d}, 1 \mathrm{H},-\mathrm{ArH}), 7.45(\mathrm{~d}, 1 \mathrm{H},=\mathrm{CH})$, $7.12(\mathrm{~d}, 1 \mathrm{H},=\mathrm{CH}), 6.02\left(\mathrm{~s}, 2 \mathrm{H},-\mathrm{OCH}_{2}\right), 3.70(\mathrm{~m}, 8 \mathrm{H},-\mathrm{CH}) ;{ }^{13} \mathrm{C} \mathrm{NMR}$ $($ DMSO-d6) $\delta(\mathrm{ppm}): 164.2,150.5,148.4,139.5,128.3,127.3,122.1$, 118.8, 108.4, 104.6, 66.2, 49.2; MS: $\mathrm{m} / \mathrm{z} 262(\mathrm{M}+\mathrm{H})^{+}$for $\mathrm{C}_{14} \mathrm{H}_{15} \mathrm{NO}_{4}$; Anal. calcd.for $\mathrm{C}_{14} \mathrm{H}_{15} \mathrm{NO}_{4}$ : C 64.36, H 5.79, $\mathrm{N}$ 5.36; Found: C 64.26, H $5.77, \mathrm{~N} 5.31 \%$.

(E)-1-morpholino-3-(2,3,4-trimethoxyphenyl)prop-2-en-1one (4i)

Color less solid in $68 \%$; $\mathrm{mp}: 196-199^{\circ} \mathrm{C}$; $\mathrm{IR}\left(\mathrm{KBr}, \mathrm{cm}^{-1}\right): 1645$ $(\mathrm{C}=\mathrm{O}), 1560(\mathrm{C}=\mathrm{C}), 1123(\mathrm{C}-\mathrm{O}) ;{ }^{1} \mathrm{H}-\mathrm{NMR}$ (DMSO-d6) $\delta: 7.20(\mathrm{~d}, 1 \mathrm{H}$, $-\mathrm{ArH}), 6.66(\mathrm{~d}, 1 \mathrm{H},-\mathrm{ArH}), 7.79(\mathrm{~d}, 1 \mathrm{H},=\mathrm{CH}), 6.87(\mathrm{~d}, 1 \mathrm{H},=\mathrm{CH}), 3.87$ $\left(\mathrm{s}, 9 \mathrm{H},-\mathrm{OCH}_{3}\right), 3.71(\mathrm{~m}, 8 \mathrm{H},-\mathrm{CH}) ;{ }^{13} \mathrm{C}$ NMR (DMSO-d6) $\delta(\mathrm{ppm})$ : 165.8, 154.6, 152.7, 142.1, 138.0, 123.0, 121.8, 115.5, 107.1, 66.4, 60.7, 60.4, 55.6, 48.2; MS: $\mathrm{m} / \mathrm{z} 308(\mathrm{M}+\mathrm{H})^{+}$for $\mathrm{C}_{16} \mathrm{H}_{21} \mathrm{NO}_{5}$; Anal. calcd. for $\mathrm{C}_{16} \mathrm{H}_{21} \mathrm{NO}_{5}$ : C 62.53, H 6.89, N 4.56; Found: C 62.44, H 6.86, N 4.50\%.

(E)-1-morpholino-3-(3,4,5-trimethoxyphenyl)prop-2-en-1one $(4 \mathbf{j})$

Color less solid in $68 \%$; mp: $176-179^{\circ} \mathrm{C}$; $\mathrm{IR}\left(\mathrm{KBr}, \mathrm{cm}^{-1}\right): 1666(\mathrm{C}=\mathrm{O})$, $1525(\mathrm{C}=\mathrm{C}), 1136$ (C-O); ${ }^{1} \mathrm{H}-\mathrm{NMR}$ (DMSO-d6) $\delta: 7.04$ (s, 2H, -ArH), $7.45(\mathrm{~d}, 1 \mathrm{H},=\mathrm{CH}), 7.15(\mathrm{~d}, 1 \mathrm{H},=\mathrm{CH}), 3.62\left(\mathrm{~s}, 9 \mathrm{H},-\mathrm{OCH}_{3}\right) ;{ }^{13} \mathrm{C} \mathrm{NMR}$ (DMSO-d6) $\delta$ (ppm) : 162.0, 150.5, 138.7, 135.3, 130.7, 115.8, 107.6, 66.2, 60.6, 56.5, 44.2; MS: $\mathrm{m} / \mathrm{z} 330(\mathrm{M}+\mathrm{Na})^{+}$for $\mathrm{C}_{16} \mathrm{H}_{21} \mathrm{NO}_{5}$; Anal. calcd. for $\mathrm{C}_{16} \mathrm{H}_{21} \mathrm{NO}_{5}$ : C 62.53, H 6.89, $\mathrm{N} 4.56$; Found: C 62.44, H 6.86, N $4.50 \%$.

\section{Pharmacological Screening}

\section{Antioxidant screening (in vitro)}

The compounds $4 \mathrm{a}-\mathrm{j}$ were tested for antioxidant property by $\mathrm{DPPH}$, $\mathrm{NO}$ and $\mathrm{H}_{2} \mathrm{O}_{2}$ methods.

\section{DPPH radical scavenging activity}

The hydrogen atom or electron donation ability of the compounds was measured from the bleaching of the purple colored methanol solution of 1,1-diphenyl-1-picrylhydrazyl (DPPH). The spectrophotometric assay uses the stable radical DPPH as a reagent. $1 \mathrm{ml}$ of various concentrations of the test compounds $(25,50,75$ and $100 \mu \mathrm{g} / \mathrm{mL}$ ) in methanol were added to $4 \mathrm{ml}$ of $0.004 \%(\mathrm{w} / \mathrm{v})$ methanol solution of DPPH. After a $30 \mathrm{~min}$ incubation period at room temperature, the absorbance was read against blank at $517 \mathrm{~nm}$. The percent of inhibition (I \%) of free radical production from DPPH was calculated by the following equation

$\%$ of scavenging $=[($ A control - A sample $) /$ A blank $] \times 100 \rightarrow E q$. (1)

Where A control is the absorbance of the control reaction (containing all reagents except the test compound) and A sample is the absorbance of the test compound. Tests were carried at in triplicate.

\section{Nitric oxide (NO) scavenging activity}

Nitric oxide scavenging activity was measured by slightly modified methods of Green et al. and Marcocci et al. Nitric oxide radicals (NO) were generated from sodium nitroprusside. $1 \mathrm{~mL}$ of sodium nitroprusside $(10 \mathrm{mM})$ and $1.5 \mathrm{~mL}$ of phosphate buffer saline $(0.2 \mathrm{M}$, $\mathrm{pH} 7.4)$ were added to different concentrations $(25,50,75$ and $100 \mu \mathrm{g} /$ $\mathrm{mL}$ ) of the test compounds and incubated for $150 \mathrm{~min}$ at $25^{\circ} \mathrm{C}$ and 1 $\mathrm{mL}$ of the reaction mixture was treated with $1 \mathrm{~mL}$ of Griess reagent (1\% sulfanilamide, $2 \% \mathrm{H}_{3} \mathrm{PO}_{4}$ and $0.1 \%$ naphthyl ethylenediamine dihydrochloride). The absorbance of the chromatophore was measured at $546 \mathrm{~nm}$. Nitric oxide scavenging activity was calculated by using Equation (1).

\section{Hydrogen peroxide $\left(\mathrm{H}_{2} \mathrm{O}_{2}\right)$ scavenging activity}

The $\mathrm{H}_{2} \mathrm{O}_{2}$ scavenging ability of the test compound was determined according to the method of Ruch et al. A solution of $\mathrm{H}_{2} \mathrm{O}_{2}(40 \mathrm{mM})$ was prepared in phosphate buffer ( $\mathrm{pH}$ 7.4). 25, 50, 75 and $100 \mathrm{~g} / \mathrm{ml}$ concentrations of the test compounds in $3.4 \mathrm{ml}$ phosphate buffer were added to $\mathrm{H}_{2} \mathrm{O}_{2}$ solution $(0.6 \mathrm{~mL}, 40 \mathrm{mM})$. The absorbance value of the reaction mixture was recorded at $230 \mathrm{~nm}$. The percent of scavenging of $\mathrm{H}_{2} \mathrm{O}_{2}$ was calculated by using Eq. (1)

\section{Results and Discussion}

\section{Chemistry}

Target compounds $(4 \mathrm{a}-\mathrm{j})$ were prepared as outlined in Scheme 1. In order to investigate how substituents on the phenyl ring in cinnamamides influence the activities, a mixture of substituted cinnamic acid (1a-j) and $\mathrm{SOCl}_{2}$ (which acted as both reactant and solvent) was stirred and refluxed at $80-90^{\circ} \mathrm{C}$ for $4 \mathrm{hrs}$. Remaining $\mathrm{SOCl}_{2}$ was removed by distillation under reduced pressure. Thus, the intermediate acid chloride $(2 \mathrm{a}-\mathrm{j})$ was added drop wise to $0^{\circ} \mathrm{C}$ cooled solution of morpholine (3) in dry pyridine to give product cinnamamide (4a-j) with good yield.

The structure of all newly synthesized morpholine containing cinnamamide derivatives were determined by IR, NMR and Mass spectroscopic analysis and the results were in agreement with the proposed structures. In ${ }^{1} \mathrm{H}$ NMR spectra, the aromatic protons resonated at $\delta 6.55-7.80 \mathrm{ppm}$. The morpholine ring proton resonated with two triplets around $\delta 2.50$ and 3.72 The conjugated double bond of cinnamicacid showed two doublet of which $\mathrm{C}-\mathrm{H}$ proton near to aromatic ring $(\mathrm{Ph}-\mathrm{CH}=\mathrm{HC}-)$ resonated at $\delta$ 7.11-7.99 while $\mathrm{C}-\mathrm{H}$ proton towards the carbonyl end $(\mathrm{Ph}-\mathrm{CH}=\mathrm{CH}-\mathrm{CO})$ resonated at $\delta$ 6.72-7.46. The synthesized compounds exhibited characteristic peak of 
cinnamicacid double bond appeared at $1525-1580 \mathrm{~cm}^{-1}$ and carbonyl peak appeared at $1640-1683 \mathrm{~cm}^{-1}$. ${ }^{13} \mathrm{C}$ NMR further confirmed the structures of the desired products and the $(\mathrm{M}+\mathrm{H})^{+}$molecular ion peak of all the compounds were confirmed by their molecular weights.

\section{Antimicrobial activity}

All the synthesized compounds (4a-j) were screened for their antimicrobial activity determined by well plate method $[28,29]$. The antimicrobial values showed that most of the synthesized derivatives exhibited excellent activities against different strains of bacteria and moderate activity against fungi. Ciprofloxacin and Fluconazole were used as the standard drugs for antimicrobial and antifungal testing, respectively.

Antibacterial activity: All the synthesized compounds were screened against Gram +ve bacterial strains such as Staphylococcus aureus and Bacillus subtilis and Gram -ve bacterial strains such as Klebsiella pneumoniae and Escherichia coli. The results obtained as MIC is presented in Table 1 . The Compounds $4 \mathrm{f}$ and $4 \mathrm{i}$ were showed good activity 12.5 and $6.12 \mu \mathrm{g} / \mathrm{mL}$ respectively against the Gram positive bacterial strain Staphylococcus aureus, when compared with standard ciprofloxacin $(12.5 \mu \mathrm{g} / \mathrm{mL})$. When Bacillus subtilis was introduced as another Gram positive bacterial strain for conducting the antibacterial test, it was found that $4 \mathrm{~b}$ and $4 \mathrm{i}$ both compounds were also exhibited good activity $12.5 \mu \mathrm{g} / \mathrm{mL}$ equivalent to the standard ciprofloxacin. Some of the compounds $4 \mathrm{~b}, 4 \mathrm{c}, 4 \mathrm{e}$ and $4 \mathrm{j}$ were screened moderate activity and rest of the compounds $4 \mathrm{~d}$ and $4 \mathrm{~g}$ was does not show any activity against Gram +ve bacterial strains. The compounds $4 \mathrm{~b}$ and $4 \mathrm{i}$ were showed MIC value $25 \mu \mathrm{g} / \mathrm{mL}$ equivalent to that reported by the standard ciprofloxacin $(25 \mu \mathrm{g} / \mathrm{mL})$ against Gram negative bacterial strain Klebsiella pneumonia. When E.coli was introduced as another gramnegative strain for conducting the antibacterial test, it was found that Compounds $4 \mathrm{f}$ and $4 \mathrm{i}$ were exhibited MIC value $12.5 \mu \mathrm{g} / \mathrm{mL}$ equivalent to that reported by the standard ciprofloxacin $(12.5 \mu \mathrm{g} / \mathrm{mL})$ against Gram negative bacterial strain Escherichia coli. Some of the compounds $4 \mathrm{c}, 4 \mathrm{e}$ and $4 \mathrm{j}$ showed less MIC values and $4 \mathrm{~g}$ compound does not show any activity against Gram negative bacterial strains. By comparing all these values, the compound which is having highest electron releasing substituent on benzene ring in cinnamamide derivative was found potent activity against all the tested organisms (Table 1).

Antifungal activity: All the synthesized compounds $4 a-j$ was also screened for their antifungal activity against two fungal strains such as Candida albicans and Aspergillus flavus. Fluconazole was taken as a standard drug throughout the experiment. Compound $4 \mathrm{~b}$ was found to be the excellent and potent antifungal activity with MIC $3.12 \mu \mathrm{g} /$ $\mathrm{mL}$ and $6.25 \mu \mathrm{g} / \mathrm{mL}$ against C. albicans and A. flavus respectively, while standard drug Fluconazole with $6.25 \mu \mathrm{g} / \mathrm{mL}$. Only two compounds $4 \mathrm{i}$ and $4 \mathrm{j}$ were also showed good activity with $3.12 \mu \mathrm{g} / \mathrm{mL}$ and $6.25 \mu \mathrm{g} / \mathrm{mL}$ against Aspergillus flavus and Candida albicans respectively and rest of the compounds $4 \mathrm{c}, 4 \mathrm{a}, 4 \mathrm{~d}, 4 \mathrm{f}$ exhibit very poor activity compared with standard Fluconazole (Table 1).

\section{Antioxidant screening (in vitro)}

In the present study, the antioxidant activity of the synthesized compounds was assessed in vitro by the 1,1-diphenyl-2- picrylhydrazyl (DPPH) radical scavenging assay, nitric oxide (NO) and hydrogen peroxide (H2O2) [30-34]. These methods were based on measuring the continual absorbance decrease of the methanolic solution of the DPPH at $517 \mathrm{~nm}$, in the presence of antioxidant compound. The DPPH has an odd electron so it can accept an electron or hydrogen free radical. In the presence of antioxidant, this odd electron becomes paired due to $\mathrm{H}$ transfer from antioxidant and hence DPPH absorbance decreases. The ability of newly synthesized compounds (4a-j) act as hydrogen donors or free radical scavengers was tested by in vitro antioxidant assays involving DPPH radical, $\mathrm{NO}$ radical, $\mathrm{H}_{2} \mathrm{O}_{2}$ and the results were compared with that of standard antioxidant Ascorbic acid. In DPPH method, the newly synthesized compounds showed moderate to good antioxidant activity compared to the standard (Table 2). Among the newly synthesized compounds $4 \mathrm{f}, 4 \mathrm{i}$ and $4 \mathrm{j}$ were found to be good antioxidant activity compared with that of the standard Ascorbic acid $(18.33 \pm 0.04)$ with the $\mathrm{IC}_{50}$ values $19.44 \pm 0.14,19.43 \pm 0.08$ and 19.09 $\pm 0.09 \mu \mathrm{g} / \mathrm{mL}$ respectively. Some of the compounds $4 \mathrm{c}, 4 \mathrm{e}$ and $4 \mathrm{~g}$ were exhibited moderate activity with the $\mathrm{IC}_{50}$ values $21.06 \pm 1.23,21.44 \pm$ 0.33 and $20.04 \pm 1.18 \mu \mathrm{g} / \mathrm{mL}$ respectively and the remaining compounds $4 \mathrm{a}$ and $4 \mathrm{~b}$ were exhibited less activity and compounds $4 \mathrm{~d}$ and $4 \mathrm{~h}$ were does not showed any activity. In DPPH scavenging method only two compounds $4 \mathrm{i}$ and $4 \mathrm{j}$ showed good antioxidant activity because of these two compounds having more electron releasing methoxy groups on phenyl ring in cinnamamide.

Further all the newly synthesized compounds were subjected to the $\mathrm{NO}$ radical scavenging activity. The $\mathrm{IC}_{50}$ value of $\mathrm{NO}$ is the concentration of sample required to inhibit $50 \%$ of the NO radicals. Except $4 \mathrm{~b}$ and $4 \mathrm{~d}$ all the tested compounds exhibited strong NO radical scavenging with moderate to good $\mathrm{IC}_{50}$ values. The greater NO radical scavenging

\begin{tabular}{|c|c|c|c|c|c|c|}
\hline \multirow{4}{*}{ Compound } & \multicolumn{6}{|c|}{ Minimum inhibitory concentration (MIC) $\left(\mu \mathrm{g} \mathrm{mL}^{-1}\right)$} \\
\hline & \multicolumn{4}{|c|}{ Antibacterial activity } & \multirow{2}{*}{\multicolumn{2}{|c|}{ Antifungal activity }} \\
\hline & \multicolumn{2}{|c|}{ Gram + Ve bacteria } & \multicolumn{2}{|l|}{ Gram -Ve bacteria } & & \\
\hline & S. aureus & B. subtilis & K. pneumonia & E.coli & C. albicans & A. flavus \\
\hline $4 a$ & 100 & 50 & $>100$ & 100 & 50 & 100 \\
\hline 4b & 25 & 12.5 & 25 & 50 & 3.12 & 6.25 \\
\hline 4c & 25 & 50 & 50 & 100 & 50 & 100 \\
\hline 4d & - & - & 100 & 50 & 25 & 50 \\
\hline $4 e$ & 25 & 50 & 50 & 25 & 100 & 50 \\
\hline $4 f$ & 12.5 & 25 & 100 & 12.5 & 50 & $>100$ \\
\hline $4 g$ & - & - & $>100$ & 50 & - & - \\
\hline $4 \mathrm{~h}$ & 50 & 100 & - & - & 100 & $>100$ \\
\hline $4 i$ & 6.12 & 12.5 & 25 & 12.5 & 12.5 & 3.12 \\
\hline $4 j$ & 25 & 25 & 50 & 25 & 6.25 & 12.5 \\
\hline Ciprofloxacin & 12.5 & 12.5 & 25 & 12.5 & - & - \\
\hline Fluconazole & - & - & - & - & 6.25 & 6.25 \\
\hline
\end{tabular}

(-) No activity. Lower MIC values indicate higher the antimicrobial activity.

S. aureus: Staphylococcus aureus, B. subtilis:Bacillus subtilis, K. pneumonia: Klebsiella pneumonia, E.coli: Escherichia coli, C. albicans: Candida albicans. Table 1: Antimicrobial activity (MIC profiles) of the synthesized compounds $(\mathbf{4 a} \mathbf{a}-\mathbf{j})$. 
activity of the tested compounds was showed by compounds $4 \mathrm{i}$ and $4 \mathrm{j}$ showed $18.33 \pm 0.09$ and $18.86 \pm 0.97$ respectively (Table 3 ).

The prepared compounds (4a-j) having various concentrations $(25,50,75$ and $100 \mu \mathrm{g} / \mathrm{mL})$ were subjected to $\mathrm{H}_{2} \mathrm{O}_{2}$ radical scavenging activity. The findings of present study (Table 4 ) indicated that the most of the prepared compounds exhibited moderate to good radical scavenging ability. The good $\mathrm{H}_{2} \mathrm{O}_{2}$ scavenging effect was detected in compounds $4 \mathrm{i}$ and $4 \mathrm{j}$ with the values of $\mathrm{IC}_{50} 18.02 \pm 0.09$ and 18.33 \pm 0.10 respectively compared with the standard Ascorbic acid (17.80 \pm 0.08 ). Rest of the compounds $4 \mathrm{e}, 4 \mathrm{f}$, and $4 \mathrm{~g}$ were showed moderate activity with $\mathrm{IC}_{50}$ values $20.76 \pm 1.33,20.01 \pm 0.20$ and $19.43 \pm 0.16$ respectively and the compounds $4 \mathrm{a}, 4 \mathrm{~b}, 4 \mathrm{c}$, and $4 \mathrm{~d}$ exhibited less activity The reason would be the presence of electron releasing methoxy groups present on the phenyl ring.

Structure activity relationship (SAR) study was helped to reveal the effect of different substituent on the microbial strains, depending upon the different electronic environments developed on the aromatic ring by substituting the electron donating groups. It was observed that the compounds $4 \mathrm{j}\left(3,4,5-\mathrm{OCH}_{3}\right), 4 \mathrm{i}\left(2,3,4-\mathrm{OCH}_{3}\right), 4 \mathrm{f}\left(2,4-\mathrm{OCH}_{3}\right)$ and $4 \mathrm{~b}$ (2-Cl) with electronic donating groups exhibited good antimicrobial

\begin{tabular}{|c|c|c|c|c|c|}
\hline \multirow{2}{*}{ Compound } & \multicolumn{5}{|c|}{ Concentration $\left(\mu \mathrm{g} \mathrm{mL}^{-1}\right)$} \\
\hline & 25 & 50 & 75 & 100 & IC $_{50}$ \\
\hline $4 a$ & $56.21 \pm 0.76$ & $57.15 \pm 0.62$ & $59.75 \pm 0.65$ & $60.20 \pm 0.94$ & $22.23 \pm 0.30$ \\
\hline $4 b$ & $54.32 \pm 0.27$ & $55.35 \pm 0.93$ & $57.25 \pm 0.07$ & $61.16 \pm 0.97$ & $23.01 \pm 1.41$ \\
\hline 4c & $59.35 \pm 0.25$ & $60.34 \pm 0.18$ & $62.46 \pm 0.16$ & $64.16 \pm 0.72$ & $21.06 \pm 1.23$ \\
\hline $4 d$ & - & - & - & - & - \\
\hline $4 e$ & $58.29 \pm 0.64$ & $62.24 \pm 0.96$ & $64.54 \pm 1.08$ & $68.72 \pm 0.98$ & $21.44 \pm 0.33$ \\
\hline $4 f$ & $64.29 \pm 0.27$ & $65.26 \pm 0.17$ & $66.72 \pm 0.23$ & $67.14 \pm 0.10$ & $19.44 \pm 0.14$ \\
\hline $4 g$ & $62.35 \pm 0.10$ & $62.66 \pm 0.36$ & $63.49 \pm 0.89$ & $69.14 \pm 1.06$ & $20.04 \pm 1.18$ \\
\hline $4 \mathrm{~h}$ & - & - & - & - & - \\
\hline $4 \mathbf{i}$ & $64.32 \pm 0.09$ & $66.13 \pm 0.20$ & $67.14 \pm 0.61$ & $72.14 \pm 0.02$ & $19.43 \pm 0.08$ \\
\hline $4 j$ & $65.45 \pm 0.22$ & $68.29 \pm 0.92$ & $70.39 \pm 0.12$ & $73.28 \pm 0.90$ & $19.09 \pm 0.09$ \\
\hline Ascorbic acid & $68.04 \pm 0.18$ & $71.24 \pm 0.15$ & $72.43 \pm 0.22$ & $75.29 \pm 0.03$ & $18.37 \pm 0.04$ \\
\hline Blank & - & - & - & - & - \\
\hline
\end{tabular}

$(-)$ showed no scavenging activity. Values were the means of three replicates $\pm S D$

Table 2: The in vitro antioxidant activity of $(\mathbf{4 a}-\mathbf{j})$ in DPPH method

\begin{tabular}{|c|c|c|c|c|c|}
\hline \multirow{2}{*}{ Compound } & \multicolumn{5}{|c|}{ Concentration $\left(\mu \mathrm{g} \mathrm{mL}^{-1}\right)$} \\
\hline & 25 & 50 & 75 & 100 & IC $_{50}$ \\
\hline $4 a$ & $57.29 \pm 0.84$ & $60.16 \pm 0.72$ & $62.24 \pm 0.63$ & $63.42 \pm 0.94$ & $21.81 \pm 1.30$ \\
\hline $4 \mathrm{~b}$ & - & - & - & - & - \\
\hline 4c & $63.40 \pm 0.23$ & $64.29 \pm 0.19$ & $65.19 \pm 0.14$ & $66.18 \pm 0.78$ & $19.71 \pm 1.03$ \\
\hline $4 d$ & - & - & - & - & - \\
\hline $4 e$ & $64.10 \pm 0.64$ & $65.20 \pm 0.96$ & $67.20 \pm 1.08$ & $69.14 \pm 0.98$ & $19.50 \pm 0.64$ \\
\hline $4 f$ & $62.32 \pm 0.07$ & $66.28 \pm 0.07$ & $69.25 \pm 0.03$ & $70.24 \pm 0.10$ & $20.05 \pm 0.02$ \\
\hline $4 \mathrm{~g}$ & $63.19 \pm 0.10$ & $65.26 \pm 0.06$ & $68.76 \pm 0.89$ & $71.24 \pm 1.06$ & $19.78 \pm 0.18$ \\
\hline $4 \mathrm{~h}$ & $62.28 \pm 0.28$ & $63.16 \pm 0.17$ & $64.26 \pm 0.44$ & $69.14 \pm 1.26$ & $20.07 \pm 1.03$ \\
\hline $4 i$ & $68.19 \pm 0.06$ & $69.14 \pm 0.03$ & $72.34 \pm 0.06$ & $76.14 \pm 0.22$ & $18.33 \pm 0.09$ \\
\hline $4 \mathrm{j}$ & $66.27 \pm 0.30$ & $68.16 \pm 0.62$ & $71.32 \pm 0.12$ & $74.29 \pm 0.40$ & $18.86 \pm 0.97$ \\
\hline Ascorbic acid & $69.24 \pm 0.23$ & $72.16 \pm 0.02$ & $76.29 \pm 0.21$ & $78.31 \pm 0.15$ & $18.05 \pm 0.05$ \\
\hline Blank & - & - & - & - & - \\
\hline
\end{tabular}

$(-)$ showed no scavenging activity. Values were the means of three replicates \pm SD

Table 3: The in vitro antioxidant activity $(\mathbf{4 a - j})$ in NO method.

\begin{tabular}{|c|c|c|c|c|c|}
\hline \multirow{2}{*}{ Compound } & \multicolumn{5}{|c|}{ Concentration ( $\left.\mu \mathrm{g} \mathrm{mL}^{-1}\right)$} \\
\hline & 25 & 50 & 75 & 100 & $\mathrm{IC}_{50}$ \\
\hline $4 a$ & $52.16 \pm 0.14$ & $54.29 \pm 0.48$ & $55.19 \pm 0.63$ & $57.29 \pm 0.72$ & $23.96 \pm 0.82$ \\
\hline $4 b$ & $53.24 \pm 0.49$ & $54.16 \pm 0.51$ & $56.28 \pm 0.14$ & $59.14 \pm 0.33$ & $23.47 \pm 1.44$ \\
\hline $4 c$ & $59.28 \pm 0.42$ & $60.24 \pm 0.69$ & $62.32 \pm 0.14$ & $64.18 \pm 0.78$ & $21.08 \pm 0.23$ \\
\hline $4 d$ & $51.20 \pm 0.64$ & $52.60 \pm 0.44$ & $54.39 \pm 0.36$ & $56.27 \pm 0.94$ & $24.41 \pm 1.25$ \\
\hline $4 e$ & $60.20 \pm 0.45$ & $61.14 \pm 0.96$ & $62.22 \pm 1.12$ & $64.19 \pm 0.38$ & $20.76 \pm 1.33$ \\
\hline $4 f$ & $62.44 \pm 0.24$ & $64.27 \pm 0.15$ & $65.29 \pm 0.56$ & $68.19 \pm 0.19$ & $20.01 \pm 0.20$ \\
\hline $4 \mathrm{~g}$ & $64.33 \pm 0.22$ & $65.28 \pm 0.15$ & $67.19 \pm 0.39$ & $70.23 \pm 1.14$ & $19.43 \pm 0.16$ \\
\hline $4 \mathrm{~h}$ & - & - & - & - & - \\
\hline $4 i$ & $69.35 \pm 0.06$ & $72.39 \pm 0.23$ & $73.14 \pm 0.16$ & $75.22 \pm 0.24$ & $18.02 \pm 0.09$ \\
\hline $4 \mathbf{j}$ & $68.16 \pm 0.20$ & $70.19 \pm 0.90$ & $71.23 \pm 0.22$ & $74.28 \pm 0.90$ & $18.33 \pm 0.10$ \\
\hline Ascorbic acid & $70.20 \pm 0.12$ & $72.14 \pm 0.09$ & $74.28 \pm 0.14$ & $76.14 \pm 0.06$ & $17.80 \pm 0.08$ \\
\hline Blank & - & - & - & - & - \\
\hline
\end{tabular}

$(-)$ showed no scavenging activity. Values were the means of three replicates $\pm S D$

Table 4: The in vitro antioxidant activity of $(4 a-j)$ in $\mathrm{H}_{2} \mathrm{O}_{2}$ method 
results, displaying moderate to good MIC values and good antioxidant properties with good $\mathrm{IC}_{50}$ values.

\section{Conclusion}

In this work conclusion, a new series of trans cinnamamides were synthesized from starting materials namely morpholine and substituted cinnamic acids with good yield. All the title compounds were screened for their antimicrobial and antioxidant activity studies. The investigation of antimicrobial and antioxidant activity screening data reveals that, among the all the compounds only few of them are exhibiting moderate to good activity. Compounds $4 \mathrm{i}$ and $4 \mathrm{j}$ showed an excellent, almost equivalent to that of standard, rest of the compounds showed moderate to mild inhibition activity.

\section{Acknowledgement}

The authors are grateful to the Council of Scientific and Industrial Research (CSIR), New Delhi, for financial assistance under a Junior Research Fellow (JRF).

\section{References}

1. Liu L, Hudgins WR, Shack S, Yin MQ, Samid D (1995) Cinnamic acid: a natural product with potential use in cancer intervention. Int J Cancer 62: 345-350.

2. Natella F, Nardini M, Di Felice M, Scaccini C (1999) Benzoic and cinnamic acid derivatives as antioxidants: structure-activity relation. J Agric Food Chem 47: 1453-1459.

3. De P, Baltas M, Bedos-Belval F (2011) Cinnamic acid derivatives as anticancer agents-a review. Curr Med Chem 18: 1672-1703.

4. Narasimhan B, Belsare D, Pharande D, Mourya V, Dhake A (2004) Esters, amides and substituted derivatives of cinnamic acid: synthesis, antimicrobial activity and QSAR investigations. Eur J Med Chem 39: 827-834.

5. Carvalho SA, da Silva EF, de Souza MV, LourenÃßo MC, Vicente FR (2008) Synthesis and antimycobacterial evaluation of new trans-cinnamic acid hydrazide derivatives. Bioorg Med Chem Lett 18: 538-541.

6. Yoya GK, Bedos-Belval F, Constant P, Duran H, DaffÃ $\odot$ M, et al. (2009) Synthesis and evaluation of a novel series of pseudo-cinnamic derivatives as antituberculosis agents. Bioorg Med Chem Lett 19: 341-343.

7. Kakwani MD, Suryavanshi P, Ray M, Rajan MG, Majee S, et al. (2011) Design, synthesis and antimycobacterial activity of cinnamide derivatives: a molecular hybridization approach. Bioorg Med Chem Lett 21: 1997-1999.

8. De P, Koumba Yoya G, Constant P, Bedos-Belval F, Duran H, et al. (2011) Design, synthesis, and biological evaluation of new cinnamic derivatives as antituberculosis agents. J Med Chem 54: 1449-1461.

9. Leslie BJ, Holaday CR, Nguyen T, Hergenrother PJ (2010) Phenylcinnamides as novel antimitotic agents. J Med Chem 53: 3964-3972.

10. Natella F, Nardini M, Di Felice M, Scaccini C (1999) Benzoic and cinnamic acid derivatives as antioxidants: structure-activity relation. J Agric Food Chem 47: 1453-1459.

11. Cutillo F, D'Abrosca B, DellaGreca M, Di Marino C, Golino A, et al. (2003) Cinnamic acid amides from Chenopodium album: effects on seeds germination and plant growth. Phytochemistry 64: 1381-1387.

12. Kato MJ, Furlan M (2007) Chemistry and evolution of the Piperaceae. Pure Appl Chem 79: 529-538.

13. Dyer LA, Dodson CD, Stireman JO 3rd, Tobler MA, Smilanich AM, et al. (2003) Synergistic effects of three Piper amides on generalist and specialist herbivores. J Chem Ecol 29: 2499-2514.

14. Richards LA, Dyer LA, Smilanich AM, Dodson CD (2010) Synergistic effects of amides from two piper species on generalist and specialist herbivores. $J$ Chem Ecol 36: 1105-1113.

15. Castral TC, Matos AP, Monteiro JL, Araujo FM, Bondancia TM, et al. (2011) Synthesis of a combinatorial library of amides and its evaluation against the fall armyworm, Spodoptera frugiperda. J Agric Food Chem 59: 4822-4827.

16. Slee DH, Romano SJ, Yu J, Nguyen TN, John JK, et al. (2001) Development of potent non-carbohydrate imidazole-based small molecule selectin inhibitors with antiinflammatory activity. J Med Chem 44: 2094-2107.

17. Guan LP, Sui X, Deng XQ, Zhao DH, Qu YL, et al. (2011) N-palmitoylethanol amide derivatives: synthesis and studies on anticonvulsant and antidepressant activities. Med Chem Res 20: 601-606.

18. Papa D, Schwenk E, Villani F, Klingsberg E (1950) The Analgesic Activity of N,N-Dialkyl Amides. J Am Chem Soc 72: 3885-3886.

19. Singh N, Sijwali PS, Pandey KC, Rosenthal PJ (2006) Plasmodium falciparum biochemical characterization of the cysteine protease falcipain-2'. Exp Parasito 112: 187-192.

20. Hirokawa Y, Kinoshita H, Tanaka T, Nakamura T, Fujimoto K, et al. (2009) Pleuromutilin derivatives having a purine ring. Part 2: Influence of the central spacer on the antibacterial activity against Gram-positive pathogens. Bioorg Med Chem Lett 19: 170-174.

21. Fung HB, Kirschenbaum HL, Ojofeitimi BO (2001) Linezolid: an oxazolidinone antimicrobial agent. Clin Ther 23: 356-391.

22. Yoshida K, Nakayama K, Yokomizo Y, Ohtsuka M, Takemura M, et al. (2006) MexAB-OprM specific efflux pump inhibitors in Pseudomonas aeruginosa. Part 6: Exploration of aromatic substituents. Bioorg Med Chem 14: 8506-8518.

23. Takeuchi H, Nakato K, Hattori H, Sonoda R, Koshiya K, et al. (1997) Pharmacological studies on YM992, a novel antidepressant with selective serotonin re-uptake inhibitory and 5-HT2A receptor antagonistic activity. Eur J Pharmacol 329: 27-35.

24. Li HQ, Zhu TT, Yan T, Luo Y, Zhu HL (2009) Design, synthesis and structureactivity relationships of antiproliferative ,3-disubstituted urea derivatives. Eur $\mathrm{J}$ Med Chem 44: 453-459.

25. Chrysselis MC, Rekka EA, Kourounakis PN (2000) Hypocholesterolemic and hypolipidemic activity of some novel morpholine derivatives with antioxidant activity. J Med Chem 43: 609-612.

26. Szulawska A, Arkusinska J, Czyz M (2007) Accumulation of gamma-globin mRNA and induction of irreversible erythroid differentiation after treatment of CML cell line K562 with new doxorubicin derivatives. Biochem Pharmacol 73: 175-184.

27. Jakubowska J, Wasowska-Lukawska M, Czyz M (2008) STI571 and morpholine derivative of doxorubicin collaborate in inhibition of K562 cell proliferation by inducing differentiation and mitochondrial pathway of apoptosis. Eur $\mathrm{J}$ Pharmacol 596: 41-49.

28. Koneman EW, Allen SD, Winn WC, et al. (1997) Colour Atlas and Textbook of Diagnostic Microbiology, Lippincott Raven Pub, Philadelphia, 86-856.

29. NCCLS (2002) Reference Method for Broth Dilution Antifungal Susceptibility Testing of Yeasts Approved Standard, second ed. ISBN 1-56238- 469-4 NCCLS document M27-A2.

30. Burits M, Bucar F (2000) Antioxidant activity of Nigella sativa essential oil. Phytother Res 14: 323-328.

31. Cuendet M, Hostettmann K, Potterat O, Dyatmiko W (1997) Iridoid Glucosides with Free Radicals Scavenging properties from Fagvaea blumei. Helv Chim Acta 80: 1144-1152.

32. Green LC, Wagner DA, Glogowski J, Skipper PL, Wishnok JS, et al. (1982) Analysis of nitrate, nitrite, and [15N]nitrate in biological fluids. Anal Biochem 126: $131-138$.

33. Marcocci L, Maguire JJ, Droy-Lefaix MT, Packer L (1994) The nitric oxidescavenging properties of Ginkgo biloba extract EGb 761. Biochem Biophys Res Commun 201: 748-755.

34. Ruch RJ, Cheng SJ, Klaunig JE (1989) Prevention of cytotoxicity and inhibition of intercellular communication by antioxidant catechins isolated from Chinese green tea. Carcinogenesis 10: 1003-1008. 